\title{
Super PACs and Financing the 2012 Presidential Election
}

\author{
Girish J. Gulati
}

Published online: 21 August 2012

(C) Springer Science+Business Media, LLC 2012

A free and fair electoral process is the primary mechanism for holding political power accountable in a democratic society. Money, for better or for worse, is an essential ingredient for facilitating elections that are competitive and substantively meaningful. Money allows candidates and political parties to organize voter registration and get-out-the-vote drives. Money also enables candidates to travel for meeting directly with voters and to communicate with and inform voters through the mass media and direct mail about their issue positions, leadership qualities, record in office, the rationale for their candidacy, and failings of their opponents. ${ }^{1}$

Without substantial amounts of money, it is unlikely that any candidate for national office can assemble the professional and sophisticated organization that is needed to wage a competitive campaign. Every election cycle requires even more money than the previous one to meet the demands of population growth, the rising costs for media communications, and the need to have the most up-to-date, high-end campaign technologies. Senator Barack Obama raised and spent approximately $\$ 750$ in his successful quest for the Presidency in 2008 , a total which was more than twice the

\footnotetext{
${ }^{1}$ Stephen K. Medvic, Campaigns and Elections: Players and Processes (Boston: Wadsworth, 2010); John Sides, Daron Shaw, Matt Grossmann, and Keena Lipsitz, Campaigns \& Elections: Rules, Reality, Strategy, Choice (New York: Norton, 2012).
}

\section{G. J. Gulati $(\bowtie)$}

Bentley University,

175 Forest Street,

Waltham, MA 02452, USA

e-mail: jgulati@bentley.edu amount President George W. Bush (\$350 million) and Senator John Kerry ( $\$ 315$ million) raised in 2004 and over four times the amount that Governor Bush ( $\$ 175$ million) and Vice President Al Gore ( $\$ 125$ million) raised in $2000 .^{2}$ There is little doubt that President Obama and the Republican nominee Mitt Romney together will set new records for fundraising by presidential candidates by the time the 2012 election is decided.

Democratic government is threatened, however, when a select few individuals or interests have a greater voice in the process and on public policy outcomes. Yet interest groups and wealthy individuals have been more than eager to help candidates finance their campaigns, and candidates desperate to win office or stay in office are eager to accept their assistance. This longstanding practice creates numerous opportunities for corruption of the electoral process and American democracy and, in turn, calls to control the influence that vested interests have over candidate agendas and public policy and to create a more competitive electoral environment. But with each new attempt at reform and subsequent reform of the reforms, candidates, organized interests and wealthy individuals identify new ways to circumvent the spirit of recent campaign finance reform laws and channel substantial amounts of money into the electoral process.

The most recent campaign fundraising innovation is the super PAC. Emerging from the ashes of the 2002 Bipartisan Campaign Reform Act (i.e., McCainFeingold), super PACs are political committees that are

\footnotetext{
${ }^{2}$ All campaign finance data are available from the Federal Election Commission, www.fec.gov. Also see, the Center for Responsive Politics' OpenSecrets.org for a more accessible access to campaign finance data and for updates throughout the election year, www.opensecrets.org.
} 
able to collect unlimited amounts of donations and spend unlimited amounts of money on television ads and other electioneering communications that expressly advocate the election or defeat of political candidates as long as they do not make direct contributions to any political candidate and there is no coordination of activities between the PAC and candidate.

The emergence of super PACs and their prominence in recent elections has raised both alarm and controversy. As of July 16, 111 super PACs have spent over $\$ 143$ million to influence this year's presidential and congressional elections. ${ }^{3}$ Echoing the concern of watchdog groups and political activists from the left, one Massachusetts editorial writer charged that super PACs are "ethics-deprived organizations" that "lack redeeming social value," but instead "spread fear, distort issues, squelch opportunity for meaningful debate, and are spoiling politics with irresponsible and dishonest political advertisements." ${ }^{, 4}$ Few analysts and commentators have been willing to offer as forceful of a response, but some have noted that super PACs can be instrumental in funding grass-roots activity and get-out-the vote efforts, make elections more competitive, and hold long-term incumbents accountable. ${ }^{5}$ This essay provides an initial assessment of these competing claims and also offers early insights on what super PACs are doing in this election cycle and what impact it may have on the 2012 presidential election and future elections.

\section{Super PACs: Origins, Definitions, \& Distinctions}

Political Action Committees Super PACs have little resemblance to conventional political action committees (PACs) that have existed since the 1940's. Labor unions were first to establish (PACs) as "auxiliary" political organizations in response to provisions in the Smith-Connolly Act of 1943 and Taft-Hartley Act of 1947 that prohibited unions from contributing money from their own treasuries to political candidates in federal elections. Business organizations, which had been subjected to a similar prohibition since the 1907 Tillman Act and Corrupt Practices Act of 1925, formed their own PACs in the 1960s. The Federal Election Campaign Act of 1971 required all PACs to register with the newly created Federal Election Commission (FEC) and file

\footnotetext{
$3<$ http://www.opensecrets.org/outsidespending/index.php $>$ accessed July 17, 2012. Totals are updated on a daily basis.

4 "Super PACs Peddle Political Snake Oil," February 6, 2012. <http:// www.masslive.com/opinion/index.ssf/2012/02/editorial_super_pacs_ peddle_po.html> accessed June 7, 2012.

5 Josh Kraushaar, "Learning to Love the Super PAC," National Journal, March 13, 2012. <http://www.nationaljournal.com/columns/ against-the-grain/learning-to-love-the-super-pac-20120313> accessed June 7, 2012.
}

quarterly disclosure reports on contributions and expenditures. Amendments passed in 1974 limited the maximum contribution that a PAC could make to a candidate and that an individual can make to a PAC to $\$ 5,000$ per election. ${ }^{6}$

Political action committees also have been able to participate in the electoral process by spending an unlimited amount of money on activities that target specific candidates but are conducted independent of any of the candidates seeking office. Independent expenditures are defined as expenditures for television advertisements that expressly advocate the election or defeat of any candidate and are not produced "in cooperation, consultation, or concert with, or at the request or suggestion of, a candidate, a candidate's authorized committee, or their agents, or a political party committee or its agents." Committees making independent expenditures must disclose all contributions that are in excess of $\$ 200$ and file itemized reports of all disbursements. ${ }^{7}$

Independent Expenditures-Only Committees What are regularly referred to by today's election professionals and analysts as super PACs are actually a set of political organizations designated by federal election law as independent expenditure-only committees. Unlike the traditional PAC, these committees do not contribute money to political candidates, political parties, or other political committees. Super PACs may raise unlimited sums of money from corporations, unions, associations and individuals and then spend unlimited sums of money on television advertisements and other electioneering communications to expressly advocate for or against a political candidate. Super PACs must report the sources and dollar amounts of all contributions and an itemized list of expenditures to the FEC on either a monthly or quarterly basis.

Whereas political action committees are legislative creations, super PACs owe their existence to rulings from two recent federal court decisions. The process began with the Supreme Court's 5-4 decision in Citizens United v. Federal Election Commission on January 21, 2010. The Court's ruling invalidated prohibitions on corporate and union treasury funding of independent expenditures (i.e., advertisements that expressly advocate election or defeat of a candidate) and electioneering communications (i.e., advertisements that refer to candidates) that had been in place since the 1974 Federal Election Campaign Act. ${ }^{8}$ Although the ban on direct contributions to candidates remained in

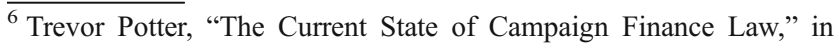
Anthony Corrado, Thomas E. Mann, Daniel R. Ortiz, and Trevor Potter, The New Campaign Finance Sourcebook (Washington, DC: Brookings, 2005).

${ }^{7}$ Federal Election Commission, "Coordinated Communications and Independent Expenditures.” <http://www.fec.gov/pages/brochures/ indexp.shtml> accessed June 7, 2012.

${ }^{8}$ Citizens United v. Federal Election Commission, 558 U.S. 50 (2010).
} 
place, unions and corporations seemed to be given more freedom to support and oppose candidates for office.

More important than the Supreme Court's ruling in Citizens United, however, was its rationale. The Court already had established in Buckley v. Valeo (1976) that communications for political advocacy was protected political speech, but that preventing corruption or the appearance of corruption was a sufficiently important governmental interest that would outweigh an individual's First Amendment interests. In the case of restrictions on independent expenditures, the Court ruled that the government has no anti-corruption interest in express political advocacy when expenditures are independent from candidates and uncoordinated with their campaigns. The absence of coordination makes it unlikely that candidates have promised favorable treatment or other improper commitments as a quid pro quo to individuals or associations making the expenditures. ${ }^{9}$ In Citizens United, the Court simply extended this reasoning to unions and corporations.

In neither the Buckley or Citizens United decisions did the Supreme Court strike down contribution limits to candidates or political action committees. The Court reasoned that there was a sufficient governmental interest in imposing contribution limits because there at least would be an appearance of corruption resulting from large individual financial contributions and that limits only marginally restrict the contributor's ability to engage in political expression. The U.S. Court of Appeals for the District of Columbia was faced with a case in which a political committee believed that contributions limits did not apply in their situation since they did not make any direct contributions to candidates. The Appellate Court agreed and in SpeechNow.org v. FEC reasoned that if the Supreme Court had ruled that there was no appearance of corruption in the case of independent expenditures, then the practice of contributions to committees that only spend on independent expenditures and make no direct contributions to candidates or PACs also cannot be considered corrupt. The Appellate Court determined, however, that there was a sufficient important governmental interest to require SpeechNow.org to organize and report to the FEC as a political committee and to adhere to the same disclosure requirements as PACs that make contributions to candidates. ${ }^{10}$

Tax-Exempt Super PACs Non-profit, tax-exempt "social welfare organization" committees also are permitted to raise unlimited sums of money from donors with no contribution limits and cannot be limited in how much money they spend on electioneering communications.

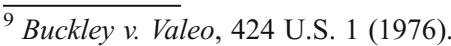

${ }^{10}$ SpeechNow.org v. Federal Election Commission, 599 F.3d 686, 689 (D.C. Cir. 2010).
}

While also referred to as super PACs in the news media because there are virtually no limits on contributions and expenditures, these committees are different in that they are authorized by Section 501(c)(4) of the U.S. Tax Code to promote the social welfare of the public. Industry associations are authorized to form similar organizations to promote their members' interests by Section 501(c)(6). Labor unions are authorized under Section 501(c)(5). All three types of 501(c)s are permitted to engage in political activities, but these activities cannot be their primary purpose. Section 501 (c) organizations are prohibited by federal law, moreover, from making contributions to presidential and congressional candidates. But unlike super PACs, the majority of electioneering communications of 501(c)s cannot explicitly advocate for or against a candidate. In addition, 501(c)s are not required to disclose the source of their contributions and their expenditures. ${ }^{11}$

Another way for interest groups to finance substantial amounts of electioneering communications is to organize a committee under Section 527 of the Tax Code. Similar to 501(c)s, Section 527 organizations also are tax-exempt, but their primary mission is to influence elections. Section 527 organizations can receive unlimited amounts of "soft money" to fund voter mobilization efforts, issue advocacy, and other activities that do not constitute express advocacy. Unlike 501(c)s, 527s must disclose all contributions and expenditures to the Internal Revenue Service and thus do not provide the anonymity that contributing to a 501(c) provides. $^{12}$ But the advantage is that their money can be used solely for partisan purposes as long as it does not cross the line into express advocacy.

The Bipartisan Campaign Reform Act of 2002 (BCRA) prohibited PACs and non-profits organizations from airing political advertisements in the 60-day period prior to an election. This prohibition was not only for "express advocacy" ads but also for "issue ads," which BCRA's authors characterized as "sham issue ads" since their clear purpose is to affect an election even though they refrain from explicitly endorsing or opposing a candidate. Wisconsin Right to Life (WRTL), a nonprofit political advocacy corporation, challenged this provision of BCRA by intending to run advertisements during the 2004 election encouraging viewers to contact the state's two U.S. Senators and tell them to oppose filibusters of judicial nominees. In FEC v. Wisconsin Right to Life, the Supreme Court sided with WRTL, finding that their ads were genuine issue ads and gave the FEC a very narrow standard for designating an ad as the equivalent to express advocacy: "only if the ad is susceptible of no

\footnotetext{
$\overline{11}$ Potter, "The Current State of Campaign Finance Law," pp. 74-5.

12 Potter, "The Current State of Campaign Finance Law," pp. 76-80.
} 
reasonable interpretation other than as an appeal to vote for or against a specific candidate."13 The implication of WTRL in combination with Citizens United and FreeSpeechNow.org was that non-profit organizations and political committees that did not make contributions to political candidates could not be limited by how much money they spent to influence an election. Moreover, there were no restrictions on where they could receive contributions and how large those contributions could be. It was just a matter of time before candidates and political activists would realize that the unlimited potential of super PACs for financing campaign communication and mobilization.

\section{Super PAC Expenditures}

The 2010 Mid-Term Elections The 2010 mid-term elections were the first elections in which the new independent expenditures-only political committees were able to participate. ${ }^{14}$ Prior to 2010 , much of the spending by outside groups on independent expenditures and electioneering communications was done by the political parties, 501(c)s, and 527s. In 2004, liberal-oriented non-profit groups spent \$121.3 million to support the presidential campaign of Democratic nominee Senator John Kerry and Democratic congressional candidates, while conservative-oriented groups spent $\$ 68.5$ million to support President Bush's reelection campaign and Republican congressional candidates. Democratic Party candidates again benefitted significantly more from independent spending by outside groups over the next two election cycles. In 2006, liberal groups outspent conservative groups $\$ 38.8$ million to $\$ 19.6$ million. The Democrats' advantage diminished somewhat in 2008, but liberal-leaning groups still outspent conservatives, $\$ 159$ million to $\$ 120.3$ million.

In 2010, Republicans and conservative groups capitalized on the new set of rules and outspent Democrats by a margin of twoto-one. All told, conservative-oriented groups spent \$190 million, while liberal-oriented groups spent only $\$ 98.5$ million. This reversal of fortunes was not due, however, to the emergence of supers PACs. Conservative super PACs outspent Democratic super PACs by less than $\$ 10$ million, $\$ 35.6$ million to $\$ 28.4$ million. Much of the surge in outside spending came from 501(c) and 527 organizations which were able to engage freely in issue advocacy and other electioneering communications without restriction during the fall as a result of the WRTL decision.

Critics of Citizens United argued that the result of the decision would be for vast sums of money to flow out of corporate treasuries. Democrats of course feared that the

\footnotetext{
${ }^{13}$ Federal Election Commission v. Wisconsin Right to Life, Inc., 551 U.S. 449 (2007)

${ }^{14}$ Michael Toner, "The Impact of the Federal Election Laws on the 2010 Midterm Election," in Pendulum Swing, Larry J. Sabato, ed., New York: Longman, 2011.
}

corporate money would be unleashed on Democratic candidates. ${ }^{15}$ Because 501(c)s do not have to reveal their donors, it is impossible to tell if the Chamber of Commerce or other conservative non-profit groups received their donations from specific corporate accounts in 2010. But it has been the practice for business-oriented PACs to donate to the campaigns of incumbent members of Congress of both parties. Moreover, anecdotal evidence indicates that businesses have been reluctant to use corporate funds for political donations in order to avoid alienating customers and their shareholders. ${ }^{16}$

An examination of the donors to some of the largest super PACs gives some insight into the impact of the Citizens United and SpeechNow.org decisions. The most prolific super PAC was American Crossroads, an organization directed by former political advisor and confidante to President George W. Bush Karl Rove, reported expenditures of $\$ 21,553,277$ to support Republican candidates in 2010. Of that total, $79 \%$ of the donations came from individuals and only $21 \%$ of the donations came from corporations. But of the nearly $\$ 19$ million in donations from individuals, $\$ 16.75$ million was contributed by just six donors with home builder Robert Perry leading the way with contributions totaling $\$ 7.5$ million. And of the $\$ 5.1$ million in corporate donations, just two companies - coal producer Alliance Resource Partners and the private holding company TRT Holdingscontributed nearly $\$ 4$ million.

The largest super PAC supporting Democratic candidates in 2010, America's Families First, reported expenditures of $\$ 5,878,743$. In contrast to American Crossroads and other Republican super PACs, two-thirds of its contributions came from organizations including \$3.4 million from labor unions.

The 2012 Presidential Election The 2012 elections are the first in which super PACs will play a significant role in campaigns for the Presidency. For the fall campaign, both President Obama and the Republican challenger Mitt Romney will have a sufficient amount of financial resources to wage their presidential campaigns. And as was the case in 2008 , the Democratic nominee will have a significant fundraising advantage. As of May 31, 2012, the Obama campaign reported receipts of $\$ 255$ million and $\$ 110$ cash-on-

\footnotetext{
${ }^{15}$ Kenneth P. Vogel, "Court Decision Opens Floodgates for Corporate Cash," The Politico, 21 January 2010. < http://www.politico.com/ news/stories/0110/31786.html > accessed June 7, 2012; Kenneth P. Vogel, "Court Ruling Sends Dems Scrambling," The Politico, 22 January 2010. <http://www.politico.com/news/stories/0110/31840 Page2.html $>$ accessed June 7, 2012

${ }^{16}$ Jennifer Schlesinger and Devin Dwyer, "2010 Election Spending Up $40 \%$, Watchdog Estimates, "ABCNews.com, October 19, 2010.< http:// abcnews.go.com/Politics/vote-2010-citizens-united-responsible-recordelection-campaign $/$ story $?$ id $=11910807 \&$ page $=2 \#$. T9FeNNUfSm0> accessed June 7, 2012.
} 
Table 1 Super PAC contributions and expenditures on behalf of 2012 presidential candidates

\begin{tabular}{lllll}
\hline Super PAC & Supporter & Spent & Raised & Candidate's Own Receipts \\
\hline Priorities USA & Barack Obama (D) & $\$ 5,758,347$ & $\$ 10,578,305$ & $\$ 217,052,304$ \\
Restore our Future & Mitt Romney (R) & $\$ 46,540,707$ & $\$ 56,512,634$ & $\$ 97,963,836$ \\
Winning our Future & Newt Gingrich (R) & $\$ 17,002,762$ & $\$ 23,907,955$ & $\$ 23,131,362$ \\
Red, White \& Blue & Rick Santorum (R) & $\$ 7,529,554$ & $\$ 8,466,221$ & $\$ 21,812,492$ \\
Endorse Liberty & Ron Paul (R) & $\$ 4,135,182$ & $\$ 3,675,479$ & $\$ 38,733,202$ \\
Make us Great Again & Rick Perry (R) & $\$ 3,959,824$ & $\$ 5,585,945$ & $\$ 19,704,786$ \\
Our Destiny PAC & Jon Huntsman (R) & $\$ 2,804,234$ & $\$ 3,189,064$ & $\$ 7,835,277$ \\
9-9-9 Fund & Herman Cain (R) & $\$ 411,055$ & $\$ 617,670$ & $\$ 16,672,939$ \\
Keep Conservatives United & Michele Bachmann (R) & $\$ 26,297$ & $\$ 27,162$ & $\$ 9,244,228$ \\
\hline
\end{tabular}

www.opensecrets.org

Totals are through April 30, 2012

hand. For the same period, the Romney campaign reported receipts of $\$ 121$ million and $\$ 17$ million cash-on-hand. ${ }^{17}$

While the Romney campaign trails the President in fundraising in the early summer, he is unlikely to be at significant disadvantage during the rest of the campaign. Unlike Republican nominee John McCain in 2008, Mr. Romney has optedout of voluntary spending limits and acceptance of federal matching funds, which would have limited him to spending only $\$ 91.2$ million between the Republican National Convention and election day. ${ }^{18}$ Candidate Obama opted-out of the public financing in 2008 and will do the same in 2012. The President is on pace to break the record $\$ 336$ million raised for the general election (and $\$ 746$ million raised overall) ${ }^{19}$ that he set in 2008 for presidential candidates and may come very near to raising $\$ 1$ billion. ${ }^{20}$

To close any remaining gaps with the President, the Romney campaign will be relying on independent expenditures from the super PACs that were instrumental in helping him best his rivals for the Republican nomination. The major super PACs supporting President Obama and the major contenders for the Republican nomination and each PAC's campaign finance totals as of May 1 are displayed in Table 1. The largest and most active super PAC so far has been Restore Our Future, which supports Mitt Romney and spent over $\$ 46.5$ million in independent expenditures on behalf of his campaign through April. The super PAC that supported Newt Gingrich, Winning

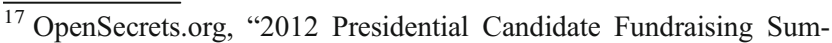
mary." < http://www.opensecrets.org/pres12/index.php>

${ }^{18}$ Federal Election Commisssion, "Presidential Spending Limits for 2012," http://www.fec.gov/pages/brochures/pubfund_limits_2012.shtml

${ }^{19}$ Michael E. Toner, "The Impact of Federal Election Laws on the 2008 Presidential Election," In Larry J. Sabato, The Year of Obama: How Barack Obama Won the White House (New York: Longman, 2010).

${ }^{20}$ Chris Cillizza, "Obama's Reelection Campaign Could Hit BillionDollar Mark, The Washington Post, 12 December 2010. <http:// www.washingtonpost.com/wp-dyn/content/article/2010/12/12/ AR2010121203181.html > accessed June 11, 2010.
}

our Future, raised \$23.9 million and spent \$17 million. Red, White \& Blue was the only other super PAC of major significance, raising $\$ 8.5$ million and spending $\$ 7.5$ million on behalf of Rick Santorum's campaign. In the end, Restore Our Future raised and spent more than the other Republican super PACs combined.

While the totals presented in Table 1 give some insight on each candidate's ability to compete financially, an examination of the funding sources for each super PAC and how the money was spent is more helpful in assessing the impact of super PACs on elections and for the democratic process more generally. In Tables 2 and 3, the largest individual and organizational donors and the amount of their donations are presented for each of the major Republican candidates and President Obama. The top individual donor to Priorities USA was DreamWorks Animation's CEO Jeffrey Katzenberg, who contributed \$2 million. Contributions from just this one donor represent $19 \%$ of the total amount of contributions received by Priorities USA. And the top organizational donor, the Service Employees International Union, contributed \$1.5 million. On the whole, labor unions contributed \$1.5 million, which represents $30 \%$ of all the contributions to Priorities USA.

The donations to Mitt Romney's super PAC reveal much more variation in funding sources. The most significant difference is that $80 \%$ of contributions to Restore Our Future were from individuals. The most generous donor to Restore Our Future was homebuilder Bob Perry, who contributed $\$ 4.75$ million. Still, this large sum represented only $8.4 \%$ of the total contributions. Only $20 \%$ of contributions were from organizations. The largest corporate donor was the energy and mining firm Oxbow Corporation, which made contributions of $\$ 1.75$ million and represented only $3 \%$ of all contributions. No contributions came from any publically-traded Fortune 500 companies.

The super PACs of all the other Republican candidates except for Texas Governor Rick Perry received over $90 \%$ of its contributions from individual donors. Unlike $\mathrm{Mr}$. 
Table 2 Sources of donations by individuals to super PACs of 2012 presidential candidates

\begin{tabular}{|c|c|c|c|c|c|}
\hline Super PAC & Candidate & $\%$ from individuals & Top Individual Donor, Occupation & Contribution Amount & $\%$ of total raised \\
\hline Priorities USA & Obama & $63 \%$ & Jeffrey Katzenberg, film producer & $\$ 2$ mil & $18.9 \%$ \\
\hline Restore our Future & Romney & $80 \%$ & Bob Perry, real estate developer & $\$ 4.75$ mil & $8.4 \%$ \\
\hline Winning our Future & Gingrich & $99.9 \%$ & Sheldon Adelson, casino owner & $\$ 21 \mathrm{mil}$ & $52.3 \%$ \\
\hline Red, White \& Blue & Santorum & $97 \%$ & William Dore, energy executive & $\$ 2.25$ mil & $26.6 \%$ \\
\hline Endorse Liberty & Paul & $99.8 \%$ & $\begin{array}{l}\text { Peter Thiel, invest. company } \\
\text { president }\end{array}$ & $\$ 2.6$ mil & $70.7 \%$ \\
\hline Make us Great Again & Perry & 62.1 & Five separate individuals & $\$ 250,000$ each & $4.5 \%$ each \\
\hline Our Destiny PAC & Huntsman & 100 & $\begin{array}{l}\text { Jon Huntsman, Sr., chemical comp } \\
\text { CEO }\end{array}$ & $\$ 2.22$ mil & $69.7 \%$ \\
\hline 9-9-9 Fund & Cain & 100 & $\begin{array}{l}\text { Ray Larson, Director R-I- } \\
\text { International }\end{array}$ & $\$ 2,500$ & $0.4 \%$ \\
\hline $\begin{array}{l}\text { Keep Conservatives } \\
\text { United }\end{array}$ & Bachman & 100 & Bob Harris, Consultant & $\$ 26,500$ & $94 \%$ \\
\hline
\end{tabular}

www.opensecrets.org

Totals are through April 30, 2012

Romney's super PAC, one major donor was responsible for almost all of the contributions. Casino owner Sheldon Adelson contributed \$21 million to Winning Our Future and represented $52 \%$ of all contributions. Over half of all contributions to Rick Santorum's super PAC — Red, White \& Blue - were from energy executive William Dore ( $\$ 2.25$ million) and investment banker Foster Friess ( $\$ 2.1$ million). And over two-thirds of all contributions to Jon Huntsman's Our Destiny PAC, \$2.22 million, were from his father.

Table 4 displays the itemized list of expenditures for the two main super PACs supporting Barack Obama and Mitt Romney and shows that most of the contributions are being spent on producing and airing campaign advertisements on television. Priorities USA spent $\$ 5.4$ million on television ads, which represents $93 \%$ of all its expenditures through April 30 . In 2008, $56 \%$ of the Obama campaign's expenditures were for advertising, media production, and media consulting. The McCain campaign spent only $30 \%$ of its total expenditures on media. Restore Our Future spent roughly $\$ 40$ million on television ads, which accounted for $98 \%$ of all its expenditures. None of reported expenditures of Priorities USA and Restore Our Future were for traditional get-out-the-vote efforts or voter mobilization tools. The amended and final expenditure reports were not available for the other Republican candidates and, thus, are not shown in Table $4 .^{21}$

The final table provides some additional insight on the activities of super PACs and their potential impact. Whereas the super PACs of President Obama and Mitt Romney dedicated almost all of their expenditures to negative advertising, the other super

\footnotetext{
${ }^{21}$ The percentages for media expenditures in 2010 were derived from data presented in Michael M. Franz, "The Citizens United Election? Or Same as It Ever Was?," The Forum, vol. 8, no. 4, article 7. Data were not divided between super PACs and non-profit organizations.
}

PACs dedicated almost all of their expenditures to promoting their own candidates. All of Priorities USA's expenditures were reported as items for opposing Mitt Romney. And $85 \%$ of Restore Our Future's expenditures were used to oppose New Gingrich and Rick Santorum. While Winning Our Future did air a number of negative television and radio ads in South Carolina and Florida attacking Romney, $76 \%$ of all expenditures were used to promote Newt Gingrich. Similarly, while Red, White \& Blue spent approximately $\$ 500,000$ on negative television ads attacking Romney in Wisconsin, nearly $90 \%$ of all expenditures were for ads promoting Santorum.

\section{Assessments \& Conclusions: How Will Super PACs Matter in 2012?}

Super PACs are the creation of three major federal court decisions and the ashes of the 2002 Bipartisan Campaign Finance Reform. The ever-rising costs of campaigns, strict limits on individual contributions to candidates, and Barack Obama's decision to opt out of voluntary expenditure limits and public financing in 2008 also are responsible for the growth of super PACs. Super PACs now are a significant feature of the current electoral landscape. As of July 16, 674 groups are registered as a super PAC, with 111 super PACs already spending \$143 million to influence the outcome of the national elections in 2012. The total spending through July 16 for outside groups as a whole is $\$ 187.5$ million, already eclipsing what outside groups spent in 2008 (\$67.6 million) and 2010 (\$36.5 million) combined. ${ }^{22}$

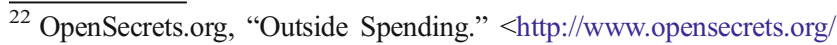
outsidespending/> accessed July 17, 2012.
} 
Table 3 Sources of donations by organizations to super PACs of 2012 presidential candidates

\begin{tabular}{|c|c|c|c|c|c|}
\hline Super PAC & Candidate & $\begin{array}{l}\% \text { from } \\
\text { organizations }\end{array}$ & $\begin{array}{l}\text { Top Individual } \\
\text { Donor, Occupation }\end{array}$ & $\begin{array}{l}\text { Contribution } \\
\text { Amount }\end{array}$ & $\begin{array}{l}\% \text { of total } \\
\text { raised }\end{array}$ \\
\hline Priorities USA & Obama & $32 \%$ & Service Employees International Union & $\$ 115$ mil & $14.2 \%$ \\
\hline Restore our Future & Romney & $20 \%$ & Oxbow Corporation, Energy \& Mining & $\$ 1.75 \mathrm{mil}$ & $3.1 \%$ \\
\hline Winning our Future & Gingrich & $0.01 \%$ & Earthworks & $\$ 1,000$ & $<1 \%$ \\
\hline Red, White \& Blue & Santorum & $3 \%$ & Kimber Manufacturing & $\$ 200,000$ & $2.4 \%$ \\
\hline Endorse Liberty & Paul & $0.03 \%$ & Polka Dot Publishing & $\$ 10,000$ & $0.2 \%$ \\
\hline Make us Great Again & Perry & $37.9 \%$ & Contran Corporation & $\$ 1 \mathrm{mil}$ & $17.9 \%$ \\
\hline Our Destiny PAC & Huntsman & $0 \%$ & $\mathrm{n} / \mathrm{a}$ & $\mathrm{n} / \mathrm{a}$ & $\mathrm{n} / \mathrm{a}$ \\
\hline 9-9-9 Fund & Cain & $0 \%$ & $\mathrm{n} / \mathrm{a}$ & $\mathrm{n} / \mathrm{a}$ & $\mathrm{n} / \mathrm{a}$ \\
\hline Keep Conservatives United & Bachman & $0 \%$ & $\mathrm{n} / \mathrm{a}$ & $\mathrm{n} / \mathrm{a}$ & $\mathrm{n} / \mathrm{a}$ \\
\hline
\end{tabular}

www.opensecrets.org

Totals are through April 30, 2012

What is not yet clear is what impact all this money flowing from wealthy individuals, labor unions, and corporations to fund mostly attack ads is having on election outcomes and what it will mean for our democratic society. In the short-run, Republicans have been quick to capitalize on this new financing mechanism and seem to be the primary beneficiaries. Because the context of the last mid-term elections strongly favored the GOP, however, it would be a leap to say that Republicanoriented super PACs, 501c organizations, and 527 committees were responsible for the Republicans' takeover of the House and other major victories in 2010. Research is needed to show precisely what contribution money had on the outcomes of individual races when controlling for other variables.

Research also is needed to assess the impact of expenditures by super PACs on the contest for the Republican nomination. Until then it would be a mistake to conclude that Romney's winning of the nomination was the result of independent expenditures by Restore Our Future or money more generally. Mr. Romney began the race as the frontrunner. He campaigned for the nomination in 2008 and won

Table 4 Itemized expenditures for Obama and Romney super PACs

\begin{tabular}{lll}
\hline & $\begin{array}{l}\text { Priorities USA } \\
\text { (Obama) }\end{array}$ & $\begin{array}{l}\text { Restoring Our } \\
\text { Future (Romney) }\end{array}$ \\
\hline Total expenditures & $\$ 5.8 \mathrm{mil}$ & $\$ 48 \mathrm{mil}$ \\
TV ad buys & $\$ 5.4 \mathrm{mil}$ & $\$ 40.4 \mathrm{mil}$ \\
Radio ads & $\$ 0$ & $\$ 0$ \\
Email/Internet advertising & $\$ 253,018$ & $\$ 1.07 \mathrm{mil}$ \\
Media production & $\$ 211,028$ & $\$ 589,430$ \\
Print Advertising & $\$ 0$ & $\$ 10,424$ \\
Direct mail & $\$ 0$ & $\$ 3.6 \mathrm{mil}$ \\
Phone calls & $\$ 0$ & $\$ 986,352$ \\
\hline
\end{tabular}

www.fec.gov

Totals are through April 30, 2012 eleven primaries and caucuses. Romney had been organizing in key states and raising money longer than most of his rivals. The former Massachusetts Governor also had the most appeal among moderate and "mainstream" Republicans and also among independents. Yet, money surely was a contributing factor. Money spent on television advertising allowed Romney to define himself and to convey his message to Republican voters who still did not have a clear picture of who he is and were not firmly committed to any candidate. Negative ads by Restore Our Future and the Romney campaign also were helpful in defining Mr. Gingrich, Mr. Santorum, and the other candidates in a negative light.

At the same time, it was money spent by super PACs that allowed the race to go on as long as it did. Super PACs provided Romney's rivals with more than enough resources to wage a viable campaign, to stay in the race longer, and to give Republican voters in many more states a choice and more of a say in who their nominee would be. A similar phenomenon is being observed in the congressional races, where super PACs have financed millions in ads for credible yet underfunded challengers in their races to unseat senior members of Congress or to compete for open seats against anointed frontrunners. The Campaign for Primary Accountability, moreover, has targeted 15 current members of Congress of both parties who have been under ethical clouds and as a result has given voters more information with which to hold their own representatives accountable for their performance. ${ }^{23}$

At the moment, the evidence is mixed on the extent to which super PACs and the practice of unlimited contributions and expenditures are corrupting the democratic process. There

\footnotetext{
${ }^{23}$ Paul Kane, "One Super PAC Takes Aim at Incumbents of Any Party," The Washington Post 7 March 2012. < http://www.washingtonpost.com/ politics/one-super-pac-takes-aim-at-incumbents-of-any-party/2012/03/ 07/gIQAhOfwxR_story.html> accessed June 11, 2012; Danny Yadron and Nathan Koppel, "PACs Fuel Congressional Challenges," Wall Street Journal 30 May 2012, p. A1.
} 
Table 5 Super PAC expenditures by targeted opponent for 2012 presidential candidates

www.opensecrets.org

Totals are through April 30, 2012

\begin{tabular}{lllll}
\hline Super PAC & Total Spent & $\begin{array}{l}\% \text { in Support } \\
\text { of Candidate }\end{array}$ & $\begin{array}{l}\text { Percent Against } \\
\text { Candidate of } \\
\text { Other Party }\end{array}$ & $\begin{array}{l}\text { Percent Against } \\
\text { Candidate of } \\
\text { Same Party }\end{array}$ \\
\hline Barack Obama & $\$ 5,758,347$ & $0.0 \%$ & $100 \%$ & $0.0 \%$ \\
Mitt Romney & $\$ 46,540,707$ & $14.6 \%$ & $0.04 \%$ & $85.4 \%$ \\
Newt Gingrich & $\$ 17,002,762$ & $76.3 \%$ & $0.0 \%$ & $23.7 \%$ \\
Rick Santorum & $\$ 7,529,554$ & $89.5 \%$ & $0.0 \%$ & $10.5 \%$ \\
Ron Paul & $\$ 3,801,091$ & $100 \%$ & $0.0 \%$ & $0.0 \%$ \\
Rick Perry & $\$ 3,959,824$ & $100 \%$ & $0.0 \%$ & $0.0 \%$ \\
Jon Huntsman & $\$ 2,804,234$ & $100 \%$ & $0.0 \%$ & $0.0 \%$ \\
Herman Cain & $\$ 411,055$ & $100 \%$ & $0.0 \%$ & $0.0 \%$ \\
Michele Bachman & $\$ 26,297$ & $8.2 \%$ & $0.0 \%$ & $73.7 \%$ \\
\hline
\end{tabular}

is no evidence to suggest that large corporate firms are drawing from their treasuries to fund political candidates. Labor unions have been active contributors to Democratic-oriented super PACs, but the size of their donations does not show an ability or at least willingness to spend much more than they have in previous elections. Moreover, the super PACs to which the unions have contributed are using some of the contributions to fund activities that register voters and get them to the polls on election day. ${ }^{24}$

Very wealthy individuals who have made their fortune in the corporate world are contributing large sums of money to Republican-oriented super PACs, but no one individual's contributions to Restore Our Future has represented even $10 \%$ of all contributions. While homebuilder Bob Perry contributed one-third of the donations to American Crossroads in 2010, expenditures were spread out over 40 different congressional races. Presidential candidates such as Newt Gingrich and Rick Santorum have relied primarily on one individual to fund their super PACs, but neither of these candidates had a rationale for their candidacies that appealed to a broad segment of the Republican electorate both in terms of votes and fundraising. While still troublesome, this practice is not any worse than allowing wealthy individuals to draw as much as they want from their own personal fortune to fund their campaigns.

What minimizes the corrupting influence of super PACs is that the names of all individual and organizational donors have to be made public. Public disclosure allows voters to decide whether they are uncomfortable or worried about the source or size of any contributions. Moreover, these extraordinary contributions garner extensive media coverage not only during the campaign, but once the candidate assumes office. It is likely that any policy decision that benefits a donor will be highly scrutinized and perceived with suspicion. Rather than concern ourselves with novel and elaborate ways to close a loophole created in the previous round of reforms, Congress

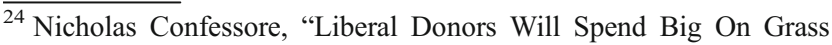
Roots," The New York Times 7 May, 2012, p. 1.
}

simply should require all tax-exempt, non-profit organizations that participate in elections to reveal their donors.

Another area of reform is to define more precisely what "coordination" for independent expenditures mean. There are too many examples of people managing a super PAC who have worked closely with the candidate or candidates their super PAC is supporting. While there may not be direct communication between representatives of the campaign and the super PAC, it is possible individuals working for a super PAC were included in strategy sessions earlier in the candidate's campaign and may have even been instrumental in formulating the message and the responsibilities of various parts of the campaign. ${ }^{25}$ It might be necessary for the Congress and the FEC to look beyond observable practices to trigger a violation and instead simply prohibit a super PAC from employing or receiving assistance from any person who has been on a campaign of a candidate the super PAC is targeting in the past 2 years.

There still is a concern that the wealthy and highly organized will be able to dictate outcomes indirectly because their large contributions force policymakers to pay attention to their arguments, while most of the public have no real voice in the policy process. Those with a seat at the table have the opportunity to influence the content of policy and limit the alternatives under debate. The First Amendment's freedom to petition makes it difficult to restrict access to legislators and other policymakers. For that reason, it is essential that those with expertise in the policy area in question monitor closely and offer analysis on the policy process and then press the news media to relay this information and analysis to the public. Rather than focusing on the adoption phase of the process, it is important for the

\footnotetext{
${ }^{25}$ Stephen Braun, "Harold Hamm, Romney Oil Adviser, Also A Big Donor to Super PAC Restore Our Future," The Huffington Post 24 May 2012. <http://www.huffingtonpost.com/2012/05/23/harold-hamm-romneyoil-adviser_n_1538902.html> accessed June 11, 2012. Mike McIntire and Michael Luo, "Fine Line between "Super PAC" and Campaigns," The New York Times 25 February, 2012, p. 1.
} 
media to report on what influences policy while the policy is being formulated.

Under the current rules and practices, super PACs will be highly visible throughout the 2012 campaign. Its impact in the presidential race will be somewhat limited, however, because both the Obama and Romney campaigns will be more than adequately funded. The issue is not which candidate will have the most money, since at some point each additional dollar spent and each additional television ad aired is subject to the law of diminishing returns, which has been the case in congressional elections. With an incumbent president running for reelection and both candidates well known to the electorate, this law should apply even more so to this upcoming presidential election. What will be interesting to observe is whether the ads run by independent groups who truly are independent of the candidate and uncoordinated distract attention away from the message that the candidates want to make not only about himself but also of the other candidate. ${ }^{26}$ More attention also should be paid to lowerinformation congressional races, where less is known about the candidates and, thus, an influx of negative advertising can easily form voters' evaluations of the candidates including the incumbent. ${ }^{27}$ And lastly, it will be worth noting whether losing candidates attribute their defeat to super PACs and their opponents' fundraising achievements rather than to their own failures in terms of performance in office and appealing to voters. That is unlikely to be the case, which then should initiate another round of debate on the evils of money in politics and how to reform the way we finance campaigns. But while that debate is taking place, the party that fared poorly in 2012 will be working quickly to replicate their opponents successful manipulation of current law and find new loopholes, all while leading the debate for reform. And the cycle continues.

\section{Further Reading}

Boatright, R. 2013. Fundraising - Continuity and Change. In Campaigns on the Cutting Edge, Second Edition, Semiatin, R. (ed). Los Angeles: CQ Press.

R. Brennan Center for Justice. 2012. National Survey: Super PACs, Corruption, and Democracy: Americans' Attitudes about the Influence of Super PAC Spending on Government and the Implications for our Democracy. <http://www. brennancenter.org/content/resource/national_survey_super_ pacs_corruption_and_democracy> accessed June 11, 2012.

Corrado, A. 2010. Fund-raising Strategies in the 2008 Presidential Campaign. In J. Thurber \& C. Nelson (Eds.), Campaigns and Elections American Style (3rd ed., pp. 105-136). Boulder, CO: Westview Press.

Corrado, A., Mann, T., Ortiz, D., \& Potter, T. 2005. The New Campaign Finance Sourcebook. DC: Washington.

Currinder, M. L., \& Green, J. 2011. Money and Elections. In C. C. Craig \& D. B. Hill (Eds.), The Electoral Challenge: When Theory Meets Practice. CQ Press: Los Angeles.

Garrett, R.S. 2011. Super PACs. In Federal Elections: Overview and Issues for Congress. Congressional Research Service R42042, December 2.

Garrett, R. S. 2012. Seriously Funny: Understanding Campaign Finance Policy Through the Colbert Super PAC. Saint Louis University Law Journal, 56(spring), 711-24.

Nelson, C. 2010. Strategies and Tactics of Fundraising in 2008. In J. Thurber \& C. Nelson (Eds.), Campaigns and Elections American Style (3rd ed., pp. 93-104). Boulder, CO: Westview Press.

Whitaker, L.P., \& Lunder, E. 2008. 527 Groups and Campaign Activity: Analysis Under Campaign Finance and Tax Laws. Congressional Research Service Report RS22895, June 12.

Wright, J. H. 2003. Interest Groups and Congress: Lobbying, Contributions, and Influence. New York: Longman.

Girish J. "Jeff" Gulati is an Associate Professor of Political Science at Bentley University. His research areas are telecommunications policy, e-government, political communication \& the news media, campaigns \& elections, and representation in theory and practice.

\footnotetext{
$\overline{{ }^{26} \text { Aaron Blake }}$ and Sandhya Somashekhar, "Joe Ricketts, a Wealthy Donor, Getting Attention in Presidential Contest," The Washington Post 17 May, 2012 A01; Jim Rutenberg and Jeff Zeleny, "Billionaire Finds New Role in Effort to Defeat Obama," The New York Times 25 May 2012, p. 15.

${ }^{27}$ Ezra Klein, "PAC Clout Will Be Greater on Capitol Hill than on Pennsylvania Ave.," The Washington Post 26 April 2012.<http:// www.washingtonpost.com/business/economy/pac-clout-will-be-greateron-capitol-hill-than-on-pennsylania-ave/2012/04/26/gIQANq97jT_ story.html> accessed June 11, 2012.
} 